\title{
JAN ROMEIN EN HET ALGEMEEN MENSELIJK PATROON
}

\author{
Jo Tollebeek \\ (Aspirant N.F.W.O.)
}

\section{Het historiografische kader}

Jan Romein (1893-1962) was een man van paradoxen, van spanningen, die hij steeds weer zocht op te lossen door een dialektische 'Aufhebung' van hun componenten. Door theoretische concepten als 'wetenschap en wereldbeschouwing', 'subjectiviteit en objectiviteit', 'vrijheid en gedetermineerdheid', 'duur en verandering', 'continuiteit en discontinuiteit' niet als antithetische en elkaar uitsluitende grootheden op te vatten, maar als in elkaar grijpende elementen van een hegeliaanse trilogie slaagde hij erin menig vastgeroest geschiedfilosofisch debat een nieuwe injectie te geven. Maar ook binnen Romeins persoonlijkheid leefden dergelijke spanningsverhoudingen. Zijn ambivalente houding ten aanzien van de vaderlandse geschiedenis, voor het eerst geconstateerd door zijn promovendus I. Schöffer in een herdenkingsartikel uit 1962, is daarvan één van de markantste. Tegelijk biedt zij een ordeningsprincipe voor Romeins historiografie.

Schöffer onderscheidt in Romeins historiografische arbeid drie perioden. In de eerste periode (1914-1928) poogt de jonge student, die zich net van de theologie heeft afgewend, zich op zeer bewuste wijze los te maken van de nationale banden. De grote Wereldbrand heeft zijn horizon verruimd en hem afkerig gemaakt van 'de zichzelf inspinnende genoegzaamheid' van de Nederlandse vakhistorici, die hun blik beperkten tot het eigen nationale verleden. Zijn marxistische engagement, waarvan het internationalisme een essentiële dimensie is, kan deze reactie tegen een in zijn ogen 'parochiale' historiografie slechts versterken. Zijn voorkeur voor de hoogleraar Algemene Geschiedenis te Leiden, Huizinga, boven de hoogleraar Vaderlandse Geschiedenis, Blok, is in deze symptomatisch.

Vanaf 1928 voltrekt zich echter een wending. De breuk met de communistiche partij betekent voor Romein het begin van de beleving van een patriottisme, dat in 1932 op wetenschappelijk gebied uitmondt in een uiterst belangrijke en tegelijkertijd vernieuwende bijdrage tot de Nederlandse beschavingsgeschiedenis, zijn Geschiedenis van de Noord-Nederlandsche geschiedschrijving in de 
Middeleeuwen. In 1934 volgt de Lage landen bij de zee, een afgeronde en hanteerbare synthese die de Romeins (Jan Romein en zijn echtgenote Annie Verschoor, eveneens historica) op slag bij een breder publiek beroemd maakt. Vier jaar later verschijnt het eerste deel van de Erflaters van onze beschaving, waarmee de auteurs expliciet willen aanwijzen 'wat Europa aan Nederland verschuldigd is'. Duidelijker kan het nationaal perspectief niet worden aangeduid! En toen tegenstanders van Romeins benoeming tot hoogleraar Vaderlandse Geschiedenis aan de Universiteit van Amsterdam in 1939 de nieuwe titularis - 'een marxist!' - een gebrek aan vaderlandsliefde aanwreven, konden zijn verdedigers deze kritiek dan ook makkelijk pareren, juist door te verwijzen naar zijn werkzaamheden in het afgelopen decennium. De indrukwekkende rede die hij in november 1940 over Oorsprong, voortgang en toekomst van de Nederlandse geest in de aula van de Universiteit houdt, heeft alle twijfels verdreven.

Na 1945 ebt dit nationalisme bij Romein echter geleidelijk weg en een nieuwe wereldgerichtheid breekt door. De coloniale kwestie, waarbij de publieke opinie zich in toenemende mate anti-Indonesisch toont, de Koude Oorlog waarin Romein een onafhankelijke 'Derde Weg' verdedigt, en de binnenlandse restauratiedrang vervreemden hem opnieuw van de Nederlandse geschiedenis. De gebondenheid met de wereld als geheel en een niet meer beperkt - Europees denken worden hem tot een tweede natuur in deze periode, zo getuigt Annie RomeinVerschoor in haar Herinneringen. Niet meer de aard en de wording van de eigen natie, zelfs niet van het eigen continent, maar wel de wereldgeschiedenis trekt nu opnieuw zijn aandacht. De wereldgeschiedenis, maar dan wel bekeken 'met andere ogen'. Romein doet een ernstige poging het geijkte historiografische perspectief te verlaten. Het traditionele gezichtspunt van de geschiedschrijving is immers uitgesproken eurocentrisch. Een dergelijke visie verliest in deze tijd van 'de eenwording van de werreld' volgens Romein elke adequaatheid. Voor dit standpunt vindt hij in Toynbee een machtige, zij het niet onaangevochten autoriteit. Maar ook binnen de Nederlandse historische gemeenschap staat Romein op dit punt niet meer alleen : Huizinga's opvolger in Leiden, Th. J.G. Locher, verdedigt in 1954 eveneens die Ueberwindung des europäozentrischen Geschichtsbildes.

Het is in deze derde periode dat Romein zijn theorie van het Algemeen Menselijk Patroon (hierna afgekort als A.M.P.) en haar Afwijking uitwerkte. Kort gezegd, komt deze theorie hierop neer : de gehele wereld heeft tot op het einde van de Europese Middeleeuwen volgens één zelfde patroon geleefd, maar vanaf de Renaissance heeft zich in Europa een afwijking voorgedaan. Het oude patroon is elders, ondermeer in Azië, echter blijven voortleven; Europa werd een Afwijking van het A.M.P. 


\section{De geboorte van een theorie}

De concrete en directe aanleiding voor de A.M.P.-theorie kan gevonden worden in de Indonesië-reis die de Romeins in 1951-1952 hebben gemaakt. In 1947 is binnen universitaire kringen het plan gegroeid Romein, samen met W.F. Wertheim, een gasthoogleraarschap in Indonesië te laten vervullen. De reis van de Wertheims is pas in 1956-1957 doorgegaan, maar de Romeins zijn in 1951 vertrokken. Jan Romein geeft er op uitnodiging van de Indonesische regering twee colleges aan de Gadjah Mada-Universiteit in Jogjakarta. Annie Romein heeft in haar mémoires benadrukt dat deze reis voor haar echtgenoot een geweldige verbreding van inzicht heeft betekend. Maar misschien is het vooral de voorbereiding van de te geven colleges die de bedoelde inzichtsverbreding heeft teweeg gebracht. Na het afspringen van een Amerikareis in $1949-$ de regering van de Verenigde Staten wou de Romeins, "communisten of tenminste krypto-communisten', geen visum verstrekken - heeft Romein al zijn aandacht op het Indonesië-projekt geconcentreerd. Hij besluit de Indonesische studenten te spreken over het einde van de Europese wereldhegemonie en over de opkomst van het Aziatisch nationalisme. Beide lesreeksen verschijnen na de thuiskomst in boekvorm, onder de sprekende titels Aera van Europa (1954) en De eeuw van Azië (1956).

Het tweede thema, de opkomst, ontwikkeling en triomf van het Aziatisch nationalisme, was Romein reeds langer vertrouwd. In 1928 heeft hij Harmsworth's Mlustrated History of the World in het Nederlands bewerkt. Aan het achtste deel voegde hij er toen een hoofdstuk over Het ontwaken van Azië aan toe. Uitgever Seyffardt laat van dit hoofdstuk 2000 overdrukken maken en naar Indonesië sturen. Het prompte verbod van gouverneur-generaal De Jonge deze tekst in Indonesie te verspreiden, heeft uiteraard een omgekeerd effect en de brochure wordt door de Indonesische nationalisten van de jaren dertig gretig gelezen.

De stof voor het eerste college was niet zo maar voorhanden. De A.M.P.theorie, waarbij de ideeën van het einde van de Europese wereldmacht en van de verspreiding van het Europese levenspatroon aansluiten, krijgt slechts langzaam vaste vorm. In 1956 spreekt Romein over deze genese als een "meer schijnbaar dan wezenlijk toevallige aaneenschakeling van scholing, persoonlijke voorkeur en dwingende omstandigheden". Vier jaar vroeger heeft hij - meer concreet opgemerkt dat de A.M.P.-theorie is kunnen ontstaan doordat hij getroffen is geweest door de overeenkomsten, die onmogelijk toevallig kunnen zijn, tussen de Europese Middeleeuwen en de Aziatische realiteit van de twintigste eeuw. Ergens moet Europa, zo voelt hij intuitief aan, afgeweken zijn van een alom verspreid patroon. De Europese Middeleeuwen kent Ronein uiteraard uit zijn 
historische studies. Over de Aziatische realiteit is hij ondermeer ingelicht door zijn echtgenote, die tussen 1906 en 1910 een deel van haar jeugd op Java heeft doorgebracht. Maar ook de eigen journalistieke bedrijvigheid uit het interbellum, waarvan de resultaten zijn samengebracht in bundels als Machten van dezen tijd (1932) en Gegist bestek (1939), heeft hem een dieper inzicht in de buitenEuropese toestanden opgeleverd.

Romein kan bij de uitwerking van de A.M.P.-theorie ook teruggrijpen naar een aantal cultuurhistorische en -filosofische essays, die hij tussen 1935 en 1950 heeft gepubliceerd en waarin een aantal kernideeën van de A.M.P.-theorie in foetale vorm aanwezig zijn. De eerste aanzet tot de A.M.P.-theorie kan aangetroffen worden in het uit 1938 daterende opstel Over de menselijke waardigheid, dat Romein trouwens expliciet als een programma, als een 'karton' voor een verder te maken schilderij heeft betiteld. Hij stelt er twee cultuurmatrijzen tegenover elkaar : enerzijds de vó́rachttiende eeuwse of christelijk-middeleeuwse en anderzijds de achttiende eeuwse (het 'vrije denken' of de conceptie van de menselijke waardigheid). Terwijl het eerste patroon in Romeins ogen kan gekarakteriseerd worden door elementen als de overheersende positie van de godsdienst, een pessimistisch levensgevoel, een zondebesef, autoriteitsgeloof en een groepsgeest, treden in het tweede een golf van secularisatie, een optimisme, een geluksverlangen, het vertrouwen op de eigen rede, het individualisme, het internationalisme en het geloof in de principiële opvoedbaarheid van alle mensen op de voorgrond. Verschillende van deze elementen komen in de A.M.P.-conceptie meerdere keren voor. Een andere belangrijke studie voor de wordingsgeschiedenis van de A.M.P.-theorie is het uit 1942 daterende De vereenzaming van de mens. In dit 'overzicht van de cultuurgeschiedenis' beschrijft Romein de poly-genetische oorsprong van het individualisme, een aspect dat ook in de A.M.P.theorie een vooraanstaande plaats innam.

\section{Twee uiteenlopende cultuurmatrijzen}

Het vertrekpunt van Romeins theorie is het moeilijk te ontkennen feit dat er vanaf de Oudheid steeds een gevoel van tegenstelling tussen 'Oost' en 'West' heeft bestaan. Dat gevoel, aldus Romein, wordt in de Verlichting omgebogen tot een rationeel discussiethema, dat tot in de twintigste eeuw actueel is gebleven. Talloze factoren worden ter verklaring aangevoerd, maar telkens komt de oplossing neer op de stelling dat er 'natuurlijke', en dus wezenlijke, verschillen bestaan tussen 'de Oosterling' en 'de Westerling'. Romein stelt zich tot doel deze discussie te vernieuwen, en dit door de Oost-West-tegenstelling in een historisch perspectief te plaatsen. De historisering van deze oppositie zou haar tegelijk relativeren, wat een eerste stap zou kunnen betekenen in de rich. 
ting van haar overbrugging. Immers : door haar op een bepaald aanwijsbaar moment in de geschiedenis te laten ontstaan, zou zij een historische oppositie worden, ontdaan van een 'natuurlijk' en dus onuitwisbaar karakter.

Met dit inzicht gewapend, komt Romein tot de formulering van de theorie van het A.M.P. en haar Afwijking : eens heeft er een 'Algemeen Menselijk Patroon van Gedrag' bestaan, dat het denken en handelen tot op het einde van de Middeleeuwen heeft gereguleerd en dat in Azië, voor zover dit continent niet 'verwesterd' is, nog steeds voortleeft. Na de Middeleeuwen is er in Europa, met name in West-Europa, een afwijking van het patroon opgetreden. Het ligt voor de hand de Europese wereldhegemonie tussen 1500 en 1900 ook vanuit deze Afwijking te verklaren. Tegelijkertijd werpt deze theorie een nieuw licht op de ervaring dat de geschiedenis van de westerse Middeleeuwen in zeer veel opzichten 'oosters' aandoet en op de (daaraan complementaire) ervaring van de Európeaan die in Azië getroffen wordt door allerlei 'middeleeuwse' toestanden en opvattingen.

Maar waarin ziet Romein het historisch gegroeide verschil tussen de twee levens- en denkpatronen? Het primaire onderscheid bestaat volgens hem hierin, dat het A.M.P. is gegrond op een statische maatschappijstructuur, terwijl de Afwijking wordt gekenmerkt door een alles overheersend dynamisme. De ondergrond van de Aziatische geschiedenis is - ondanks de snelle opeenvolging van de verschillende dynastieën - eeuwenlang onbewogen gebleven. Elke economische en sociale dynamiek ontbrak, wat ondermeer tot uiting kwam in de afwezigheid van een vrije middenstand. Het Afwijkingspatroon daarentegen kan worden gekenmerkt door de categorieën 'verandering', 'vernieuwing' en 'verbetering'. Dit basisverschil schraagt volgens Romein de fundamenteel uiteenlopende visies die beide cultuurpatronen ten aanzien van de belangrijkste maatschappelijke sferen hebben. Hij spitst zijn analyse toe op volgende factoren : de natuur, het leven, het denken, de autoriteit, de tijd en de arbeid. Uit deze analyse zal moeten blijken dat beide cultuurmatrijzen grondig en totaal verschillen.

De A.M.P.-mens gebruikt de natuur weliswaar voor zijn levensonderhoud, maar hij objectiveert haar niet. Hij is niet door de gedachte bezeten de natuur haar geheimen te ontnemen teneinde haar aan zich te kunnen onderwerpen. In de Afwijking wordt de natuur een te beheersen grootheid. Dit onderscheid impliceert een verschillende houding ten aanzien van de (natuur)wetenschappen en de techniek.

Terwijl de A.M.P.-mens zich van het leven heeft onthecht door zijn wezen en geschiedenis in handen van de goden of van het Lot te leggen, wordt in de Afwijking aan het leven een souvereine waarde toegekend.

Ook de denkstructuren verschillen fundamenteel. Een concreet en op beelden gebaseerd denken staat tegenover een abstrakt en begrippelijk redeneren. Of nog: de mythische samenhangen, magische voorstellingen en symboli- 
sche zinsduidingen van het A.M.P. worden in de Afwijking vervangen door exacte waarnemingen en 'logische' redeneringen. Dit verklaart ondermeer waarom de bewuste organisatie in het A.M.P. een veel minder prominente plaats inneemt dan in de Afwijking, waarom de religieuze formaties er nooit de gedaante van een Kerk hebben aangenomen, waarom van bovenaf door de vorst geleide nationale staten in het A.M.P. onbekend zijn en waarom er zo'n bonte verscheidenheid op juridisch, ethisch, religieus en taalkundig vlak is in het A.M.P. Bij deze oppositionele denkvormen past wellicht ook een verschillend, zo mogelijk zelfs een tegengesteld waarheidsbegrip.

De macht van de autoriteit is in het A.M.P. integraal : zowel die der goden als die van de vorst, zowel die van de vader als die van de leraar en van het boek is onaangetast. Tussen absoluut gezag en chaos wordt geen midden erkend. Deze afwezigheid kan in Romeins ogen worden beschouwd als het ideologisch complement van het ontbreken van een sociaal midden. In de Afwijking daarentegen wordt elk gezag uiteindelijk afgebroken. Het neerhalen van standbeelden is er legio. De humanisten van de Renaissance verwerpen de autoriteit van de Kerk, maar aanvaarden de Oudheid als nieuwe vorm. In de Verlichting wordt de Oudheid achterhaald verklaard. Het gezag wordt nu geinterioriseerd : de menselijke rede wordt de nieuwe, en laatste, autoriteit. Maar ook die rede kent een inperking, zodat er tenslotte helemaal geen gezag meer is. Deze kritische deconstructie - Max Weber heeft er reeds op gewezen - ligt ook aan de basis van de westerse wetenschap. De uiteenlopende houding ten aanzien van de autoriteiten heeft implicaties voor de visie op verzet en revolutie. In het A.M.P. geldt het verzet als 'abjecte zonde' of als 'metafysische ontucht', terwijl het in de Afwijking wordt gerelativeerd en soms zelfs als een gebod kan verschijnen.

De A.M.P.-mens kent geen tijd: de tijd is er onwezenlijk. In het patroon van de Afwijking daarentegen functioneert de tijd als de regulator van het gehele bestaan. Dit verschil heeft zowel een economische als een culturele consequentie. In het A.M.P. kent men wel de schat, maar niet de kapitaalvorming. Het sparen is een eigenschap die slechts de mens uit het levenspatroon van de Afwijking kent. En in het culturele vlak huldigt het A.M.P. een statische geschiedbeschouwing: elke verandering in het wereldgebeuren wordt gereduceerd tot onwezenlijke schijn. De geschiedenis herhaalt zich: zij heeft een cyclisch patroon. In de Afwijking wordt een heel andere geschiedopvatting beleden : verandering en vooruitgang zijn er de essentiële kenmerken van.

\section{Het atbeidsbegrip}

Hoezeer deze beide cultuurpatronen verschillen, blijkt volgens Romein nog meer uit de uiteenlopende houding ten aanzien van het arbeidsbegrip. Zelf 
beschouwt hij deze thematiek van zo fundamenteel belang, dat hij haar een exemplarische rol toebedeelt : de verschillende visies op het arbeidsbegrip laten als het ware toe de gehéle tegenstelling te belichten.

Op 11 januari 1952 wijdt hij voor de Volksuniversiteit in Bandung een aparte lezing aan deze problematiek : Het arbeidsbegrip in Oost en West. Daarin betoogt hij dat er vanaf het einde van de Middeleeuwen in Europa een arbeidsheiliging heeft plaats gegrepen. De arbeid krijgt er een positieve morele connotatie en wordt een plicht. Tegelijk wordt het 'sociale probleem' gesteld. In het A.M.P. blijft de arbeid (een uitvloeisel van de zondeval!) een negatieve betekenis behouden. Meer werken dan nodig voor het kevensonderhoud wordt als iets tegennatuurlijks beschouwd. Daartegenover wordt in de Afwijking de arbeid tot de 'natuurlijke' toestand van de mens 'gepromoveerd'; de arbeidsdrift en de bekroning van de arbeid-om-de-arbeid duiken er op.

Nochtans, zo benadrukt Romein, komt deze verandering niet onvoorbereid. Zowel bij de Grieken als bij de Romeinen en in de westerse Middeleeuwen vindt men een aanzet. De voorzichtige objectivering van de natuur bij de Grieken, de organisatiedrang en de secularisatie van het normbesef bij de Romeinen, de plicht tot handenarbeid bij de Benediktijnen (het 'ora et labora), de geleidelijke afschaffing van de lijfeigenschap en vooral de groei der middeleeuwse steden bereiden het nieuwe arbeidsethos voor. Toch kan het slechts definitief doorbreken na een daarbij aansluitende ideologische omwenteling. Die situeert Romein in de Scholastiek en vooral in de zestiende eeuw. Het protestantisme bevordert de ontwikkeling van het kapitalisme, een intensief en expansief economisch model. Het 'arbeid adelt' doet vooral opgang in de calvinistische middens en blijft voorlopig nog in een religieuze sfeer ingebed. In de Renaissance en in de Verlichting breekt het nieuwe arbeidsethos echter geheel door. De 'volstrekte herijking van de menselijke waarden' is een feit, dat in de theorieën van Locke, Smith en Ricardo wordt bevestigd. De Industriële Revolutie zorgt voor de verdere verspreiding van het nieuwe arbeidsbegrip.

Romein ziet deze evolutie niet onbewogen aan. Hij merkt op dat de nieuwe visie op de rol en de functie van de arbeid ertoe heeft geleid dat in het Westen alles in de arbeidssfeer dreigt terecht te komen, zelfs de kunst. Hij waarschuwt met klem voor het niet denkbeeldige gevaar dat de homo economicus de andere homines (aestheticus, ludens, religiosus, amorosus ...) uiteindelijk zal verdrijven. Het Westen lijkt in een overwaardering van de arbeid te zijn vervallen. Heeft Johan Huizinga, Romeins leermeester, er al niet in 1938 op gewezen dat de homo economicus steeds meer de homo ludens dreigt weg te drukken? 


\section{De genealogie van de Afwijking}

In De Europese geschiedenis als afwijking van het Algemeen Menselijk Patroon (1952), opgenomen in de bundel In de ban van Prambanan (1954), wijst Romein erop dat de Afwijking, die (West-)Europa vanaf ongeveer 1600 een nieuwe cultuurmatrijs geeft, geen 'creatio ex nihilo' is. $Z i j$ is ontstaan uit een ingewikkelde constellatie van historische 'lijnen en patronen', zoals al uit de schets van de groei van het nieuwe arbeidsethos blijkt.

De antiek-Griekse maatschappij vertoont twee fundamentele afwijkingen van het A.M.P.: de stadstaat en het seculiere, wereldlijke karakter ervan. In samenhang daarmee wordt ook de natuur voor het eerst geobjectiveerd en wordt de mens de maat van alle dingen. Tegelijk ontstaat het 'vrije denken' : een poging de kosmos rationeel te begrijpen, en dit door onbevangen waarneming en abstrahering. De Romeinse bijdrage tot de Europese Afwijking van het A.M.P. bestaat in het sterk ontwikkelde organisatietalent, dat zich manifesteert in het vlak van staat, techniek en recht. Hiermee verdwijnt elke willekeur.

De Grieks-Romeinse afwijking zet zich echter niet onmiddellijk door. Europa schijnt in de Middeleeuwen weer geheel in het A.M.P. te passen. Toch duikt er ook in deze periode nu en dan iets van de Afwijking op. Het van de Romeinen geërfde organisatietalent en de centralistische politiek van de christelijke Kerk getuigen daarvan. Belangrijker is echter de opkomst van de middeleeuwse stad, een betrekkelijk kleine gemeenschap, geleid door zelfbewuste burgers die hun eigen recht scheppen en waarin vanaf de vijftiende eeuw het kapitalisme ontstaat. Dit kapitalisme brengt een onherstelbare breuk in het A.M.P. Het leidt niet alleen tot een nieuw arbeidsbegrip, maar ook tot een andere houding ten aanzien van de tijd, een inzicht dat Romein mede aan de socioloog Den Hollander dankt. Het tijdsbegrip wordt immers intensiever en toekomstgericht. Het psychologisch complement hiervan is de houding ontzeggingen te getroosten voor het nu teneinde daarvan later te genieten.

Ongeveer tegelijk met het kapitalisme, komt ook de Renaissance tot bloei. Zij betekent de definitieve consolidering van de Afwijking. Zij ontwikkelt zich snel van een poging het realistisch kunstideaal van de Grieken en de staatskunde van de Romeinen te revalueren tot een veel omvattender program : het overtreffen van de gehele Oudheid. Daarmee duikt ook het vooruitgangsgeloof op, een duidelijk bewijs dat het oude, statische maatschappijmodel vervangen wordt door een dynamischer model. Tegelijk is de Renaissance - Romein gaat hierbij terug tot de bekende formule van Michelet en Burckhardt - 'de ontdekking van de wereld en de mens'. De steeds groter wordende interesse voor het aardse is onmiskenbaar. Belangrijker is echter de opkomşt van het individualisme : de oude middeleeuwse gemeenschapsbanden van dorp, beroep en familie worden doorgesneden. Daarmee lijkt het A.M.P. volledig doorbroken. Toch wor- 
den nog vele Renaissance-figuren door een zekere aarzeling en gespletenheid gekenmerkt : zij worden door de vraag gekweld, of zij het oude (het A.M.P.) geheel moeten verwerpen en het nieuwe (de Afwijking) geheel moeten aanvaarden, en zo neen, in welke mate en wat dan van het oude moet worden behouden en van het nieuwe kritisch moet tegemoet getreden worden. Erasmus is in Romeins beeld zo'n typische overgangsfiguur.

Twee bewegingen, het nationalisme en het protestantisme, stimuleren de verdere groei van de Afwijking. Het nationalisme, oorspronkelijk een creatie van de koning en de burgerij tegen de universele machten, Keizer en Paus, leidt tot een groeiende macht van de burgerij, wat uitmondt in het parlementarisme en tot op zekere hoogte ook in de democratie. Het protestantisme heeft er niet alleen toe bijgedragen een nieuw arbeidsbegrip te scheppen, maar heeft ook aanleiding tot een andere houding tegenover de autoriteit gegeven. Dat laat zich vooral demonstreren aan radicale onderstromingen, zoals de wederdopers.

Nog ontbreken er drie factoren aan de volledige ontwikkeling van de Afwijking : de definitieve voltooiing van de vrije gedachte, de toepassing van de mechanische arbeidskracht en het gelijkzetten van de politieke met de sneller draaiende sociale klok. Deze factoren worden betrekkelijk snel gerealiseerd. De Verlichting verheft de rede tot opperste macht, maakt het vooruitgangsgeloof tot een onbetwijfelbare zekerheid en historiseert het hele wereldbeeld. De (Engelse) Industriële Revolutie brengt een mechanische produktiewijze, die mogelijk is geworden doordat een leger van arbeiders en grote kapitalen zijn vrijgemaakt ten gevolg van de verbetering van de landbouwmethoden. De Afwijking wordt tenslotte voltooid door de burgerlijke Amerikaanse en Franse politieke revoluties, die uiteindelijk slechts de politieke structuren in overeenstemming met de reeds bestaande sociale hiërarchie brengen.

\section{Humanisme en conservatisme}

Op dit punt gekomen, blijkt dat de A.M.P.-theorie voor Romein een alomvattend interpretatiekader voor de geschiedenis is geworden. $Z$ ij laat hem immers toe bepaalde concepten, die door veelvuldig gebruik - als pasmunt - elke glans verloren hebben, opnieuw van een begrippelijke inhoud te voorzien, en wel door ze te incorporeren in de theorie zelf. Het gaat hier om de begrippen 'humanisme' en 'conservatisme'.

In een door Annie Romein posthuum uitgegeven essay over het humanisme, Poging tot een herinterpretatie van het humanisme (1964), merkt Romein op dat de essentie van het 'historische' humanisme niet het teruggrijpen naar de klassieken is, maar wel het verlangen anders te zijn dan de middeleeuwers. Daarvoor kan hij steunen op een stelling van zijn promovendus H. Schulte 
Nordholt, die in zijn proefschrift over Het beeld der Renaissance (1948) heeft betoogd dat "de eis der vroege Renaissance tot terugkeer naar de Oudheid in wezen de voorlopige mythe is van haar vitale drang naar bevrijding en volstrekte vernieuwing". Voor Romein is het humanisme - hier sluit hij aan bij de eigen A.M.P.-theorie - de beweging, waarin voor het eerst de Afwijking van het A.M.P. bewust wordt beleefd. Zo moet men het humanisme als een essentieel onderdeel van het Europese afwijkingsproces opvatten.

Dat geldt ook voor het conservatisme. In zijn openingsrede van het vierentwintigste filologencongres te Amsterdam in 1956 beschrijft hij Het conservatisme als historische categorie. In deze lezing tracht hij het ontstaan en de inhoud van het conservatisme onder de noemer van het A.M.P.-begrip te brengen. Het aanknopingspunt daartoe is de ervaring dat binnen het levenspatroon van de Afwijking steeds ideeën hebben geleefd, die getuigen van een nostalgisch verlangen naar de oude cultuurmatrijs. Deze ideeën worden niet toevallig in de Romantiek virulent : de Industriële Revolutie, die zich juist in deze periode krachtig doorzet, wijst erop dat de weg terug naar het oude levenspatroon volledig afgesloten is. Het conservatisme kan daarom worden geinterpreteerd als de erfgenaam van de voorstellingswereld van het A.M.P. in de periode dat het patroon van de Afwijking in Europa definitief doorbreekt.

In dit perspectief wordt het conservatisme een historische categorie. Dit impliceert dat het op een bepaald moment in de geschiedenis moet ontstaan zijn. De vraag is uiteraard: wanneer? Aansluitend bij Mannheims klassieke essay Conservative Thought (1953), maakt Romein daartoe een onderscheid tussen 'traditionalisme' en 'conservatisme'. Het conservatisme wordt dan gekarakteriseerd als de bewustwording van het traditionalisme toen én doordat dit bedreigt raakte. In deze optiek begint het conservatisme natuurlijk op het moment dat het oude levenspatroon de concurrentie van een nieuw patroon krijgt, met andere woorden : op het moment dat de Afwijking zich dreigt door te zetten. Aangezien deze Afwijking zich - zo blijkt uit haar genealogie schoksgewijs heeft opgedrongen, zal het conservatisme, de bewuste reactie ertegen, een analoge wordingsgeschiedenis kennen. Romein ziet een rechtevenredig verband tussen de kracht waarmee de Afwijking zich doorzet en de duidelijkheid waarmee het conservatisme zich manifesteert. Het is dan ook normaal dat het conservatisme zijn krachtigste vormen heeft gekend ten tijde van en kort na de Franse Revolutie, die de politieke neerslag van de Afwijking betekent. Na Burke heeft het conservatisme steeds als onderstroom voortgeleefd. Het is alleen telkens dan aan de oppervlakte verschenen en revirulent geworden, wanneer er nieuwe en radicale veranderingen in de maatschappij op til schijnen of plaatsgrijpen. De facto willen deze (neo-)conservatieven steeds datgene behouden wat bestond vóórdat de Afwijking een stap verder wou gaan, omdat de Afwijking nu eenmaal niet meer als zodanig ongedaan kan worden gemaakt; 
maar in wézen is het conservatisme een verlangen naar de restauratie van de situatie vóór de Afwijking.

\section{De crisis van beide patronen}

Dat de Europese cultuurmatrijs wordt gevormd door een afwijking van de oude universele matrijs, het A.M.P., die na 1600 nog doorleeft in Azië, is echter slechts één aspect van Romeins verhaal. Het tweede aspect betreft de veranderingen die zich in de geschetste situatie hebben voorgedaan. Het Afwijkingspatroon blijkt immers zo krachtig, dat het zich ook elders laat gelden en ook daar het A.M.P. gaat verdrijven. Zodoende begint de Afwijking zich eveneens in Azië te manifesteren. Dat is het gevolg van het expansieve karakter van de westerse (Europese) beschaving. Vanaf de negentiende eeuw exporteert Europa de eigen, nieuwe cultuurmatrijs door een imperialistische politiek te voeren. Deze expansie is al rond 1600 aangevangen, maar wordt vanaf 1800 beslissend. Azië wordt door de Europeanen in een ijltempo geindustrialiseerd. Deze 'Europese inbraak' heft een aantal Aziatische misstanden op. Doch het oude Aziatische cultuurpatroon kan zich niet aan de snelle 'modernisering' aanpassen, zodat de beschaving ontwricht wordt.

De Europese politieke en economische expansie verspreidt dus ook de Europese cultuurmatrijs. Daardoor wordt de Afwijking zélf een A.M.P., zij het een ander dan het oude. Colonialisme en imperialisme impliceren een kwantitatieve verspreiding van de Afwijking over heel de wereld. Dit betekent echter niet dat de Afwijking ook kwalitatief nog wordt vergroot. Maar wat tussen vijftienhonderd en achttienhonderd als Afwijking is gegroeid, wordt tussen achttienhonderd en negentienhonderdvijftig regel. Wat eens abnormaal was, wordt normaal.

De verspreiding van de Afwijking in Azië rond negentienhonderd loopt chronologisch gelijk met twee uiterst belangrijke omwentelingen in de wereldgeschiedenis : enerzijds het einde van de Europese hegemonie en anderzijds het ontwaken van Azië. Dit worden twee grondthemata uit Romeins werk.

Rond negentienhonderd, 'op het breukvlak van twee eeuwen', komt de westerse beschaving terecht in een diepgaande crisis. Romein heeft dit proces in de donkere oorlogsjaren beschreven in De crisis van onze beschaving in historisch perspectief (1944). Daarin constateert hij dat de Europese maatschappij, die er niet in geslaagd is een geschikt evenwicht tussen vrijheid en ordening en tussen het individuele burgerschap en het gemeenschapsleven te vinden, na negentienhonderd een gedesintegreerd beeld te zien geeft. De periode 1900 . 1933 is voor hem het 'herfsttij van Europa'. Vóór negentienhonderd schijnt de situatie nochtans rooskleurig: de Europese bourgeoisie heeft alle macht naar 
zich toegetrokken, het kapitalisme bloeit, Europa's militaire superioriteit staat buiten kijf, de periode van elkaar opvolgende revoluties lijkt ten einde, de arbeiders zijn amper georganiseerd ... Maar vanaf negentienhonderd wordt de positie van deze bourgeoisie ondermijnd : zij krijgt af te rekenen met een opkomende arbeidersklasse (socialisme en anarchisme), met een toenemende bewapeningswedloop, met allerlei internationaal-politieke crises die resulteren in de Eerste Wereldoorlog, met een geslaagde anti-burgerlijke revolutie in Rusland ... Tegelijk met de hegemonie gaat ook de zekerheid verloren : politieke, ethische en culturele normen worden aangetast. 'The quest for certainty' kan beginnen.

Terwijl Europa omstreeks de eeuwwende zijn hegemonie verliest, ontwaakt Aziè. De onverwachte overwinning van Japan op Rusland in 1905 is significant. Vanaf dit moment ontrolt het Aziatisch nationalisme zich. Het evolueert van een nog feodaal verzet tegen de Europese inmenging - over een reactie van de in het Westen opgeleide intelligentsia - tot een massabeweging. Maar de verspreiding van het Afwijkingspatroon heeft Azië uit zijn voegen gelicht. Merkwaardig genoeg zet de Afwijking zich na de bevrijding van de westerse heerschappij nog sterker door. De verdringing van het A.M.P. door de Afwijking resulteert in een psychische gespletenheid bij de oosterse intelligentsia, vergelijkbaar met de toestand van de intellectuelen uit de Europese Renaissance. Azië beleeft zijn Renaissance, met het onvermijdelijke aanpassingsdilemma : in hoeverre moet het zich verwestersen (de Afwijking aanvaarden) of de traditionele identiteit behouden (het oude A.M.P. bewaren) ? Deze gespletenheid uit zich in elk levensgebied, juist omdat het om een conflict tussen twee cultuurmatrijzen gaat : zij wordt het 'Leitmotiv' van de Aziatische geschiedenis. Telkens weer staat de moderne Aziaat voor de betrekkelijke tegenstelling tussen oud en nieuw. In De garoeda broedt (1952) beschrijft Romein deze gespletenheid in psychologisch, politiek, economisch, sociaal en cultureel vlak uitgebreid. Eén van haar vormen is het dilemma van de economische modernisering: de agrarisch-feodale economie, erfenis van het oude A.M.P., en de nieuwe industrieel-kapitalistische economie, tekenend voor het Afwijkingspatroon, komen steeds opnieuw in conflict. Deze en dergelijke spanningen brengen uiteindelijk ook de Aziatische beschaving in een crisissituatie.

\section{Naar een nieuwe synthese}

De crisis van de westerse beschaving laat Europa niet meer toe een bevoorrechte positie in de wereld in te nemen. 'Europa heeft nu geen voorsprong meer, integendeel. Het ervaart het nadeel van de voorsprong die het eens had, zoals Azië het voordeel zal ervaren van de achterstand van voorheen', aldus Romein in 1952. Hij lijkt de dramatische gebeurtenissen rond negentienhonderd te wil- 
len vatten onder de 'wet van de remmende voorsprong'. In 1935 publiceert hij in het tijdschrift Forum een lang opstel over De dialektiek van de vooruitgang. Daarin constateert hij dat de geschiedenis zich niet zozeer trapsgewijs, dan wel sprongsgewijs ontwikkelt, een idee die ook Trotsky al heeft geformuleerd. Nieuwe economische inzichten bijvoorbeeld schijnen niet te groeien vanuit de op dat moment meest volmaakte bestaande systemen, maar vanuit systemen die een veel lagere graad van perfectie bezitten, zodat er steeds verspringingen optreden. Daaruit leidt Romein af dat een voorsprong op een bepaald moment en onder bepaalde omstandigheden een rem kan worden. Paradoxaal geformuleerd : "Een hoogtepunt-worden betekent achter-zijn; een hoogtepunt-zijn betekent achter-raken". De verklaring voor het feit dat een voorsprong kan omslaan in een achterstand zoekt Romein in het conservatisme en de zelfvoldaanheid, die de belangengroepen van het voorlijke systeem steeds tekenen en daardoor verdere modernisering verhinderen. Slechts éen concreet voorbeeld : de kolenmijnen in de oudere vindplaatsen (Engeland, België) hebben een lager productiviteitsgemiddelde dan die van de jonge ontginningen (Duitsland, Polen ...) omdat zij, verblind door een jarenlange industriële speerpuntfunctie, minder snel tot noodzakelijke wijzigingen in het productieschema overgaan.

Deze theorie wordt met lof onthaald. Gerretson raadt in september 1937 Romeins essay als reislectuur aan Geyl aan, die het als 'werk van betekenis'. aanstreept. Nog in 1984 peilt de Nederlandse socioloog Lammers naar de draagwijdte van de theorie voor de organisatiesociologie. Het ligt dan ook voor de hand dat Romein haar zou toepassen op de problematiek van het A.M.P. en de Afwijking. In deze optiek zou hij dan hebben kunnen concluderen dat het Afwijkingspatroon de tol voor zijn eeuwenlange voorlijkheid rond negentienhonderd moet betalen en dat het A.M.P. - als premie op de langdurige achterlijkheid - zich na de crisis van de Afwijking zou ontwikkelen tot een progressief en modern denk- en levenspatroon. Wertheim moet bij Romeins overlijden echter vaststellen dat dat niet is gebeurd. Uit de hierboven geciteerde uitspraak uit 1952 blijkt dat Romein er wél aan gedacht heeft de idee van de dialectiek van de vooruitgang in verband te brengen met het A.M.P. Dat dit inderdaad niet op systematische en vruchtbare wijze is gedaan, moet op rekening van Romeins Indonesische indrukken geschreven worden. De alomvattende gespletenheid die hij er bij de intelligentsia heeft vastgesteld, verhindert hem te geloven dat het oude en vegeterende A.M.P. zich nog kan transformeren in een nieuw en vooruitstrevend patroon.

Romein kiest voor een andere oplossing, die hem typeert : hij zoekt naar een synthese tussen het versteende A.M.P. en de in een krisis verkerende Afwijking. Het is een ideaal dat hij zich stelt, een 'concrete utopie'. Tussen A.M.P. en Afwijking moet een 'Derde Weg' worden gebaand, die de patstelling zal kunnen opheffen. De bundel In de ban van Prambanon draagt hij daarom op aan 
Roeslan Abdulgani, 'als één der eersten die een synthese tussen Oost en West bereikten'. Voor Azië impliceert een dergelijke synthese dat er moet worden gestreefd naar een verzoening, naar een 'cohabitatie' tussen de eigen traditionele waarden en de nieuwe moderne verworvenheden. Voor Europa betekent zij een terugkijken naar het oude A.M.P. zonder de winstpunten van de Afwijking prijs te geven. Geen uitschakeling maar omschakeling (de woorden zijn van Beerling), dat is het lot van het Afwijkingspatroon.

Bij deze metamorfose zullen én humanisme én conservatisme een historische rol kunnen spelen. Het hedendaagse humanisme moet de geestelijke leidraad zijn bij het scheppen van een nieuw gedragspatroon uit het voorbijgestreefde A.M.P. en de Afwijking. Het conservatisme zal daarbij moeten aanwijzen welke elementen uit het oude A.M.P. nog waardevol zijn. Een mentale synthese tussen 'Oost' en 'West' zal des te eerder mogelijk zijn, naarmate de Afwijking in Azië verder is voortgeschreden, maar evenzeer naarmate er binnen de Afwijking meer begrip aanwezig is voor wat in Azië niet afwijkt, en daar kan het conservatisme bij helpen. Met de schepping van een nieuw en hoger A.M.P. zal dan niet alleen de oppositie tussen 'Oost' en 'West' worden opgeheven, maar zal ook de ideologische tegenstelling tussen conservatisme en revolutiedrang worden opgelost. Door die rol te vervullen zullen humanisme en conservatisme in de volle zin des woords historische categorieën worden : in een explosief tijdperk zullen zij hebben bijgedragen tot de overbrugging van twee wereldbeelden.

\section{Tot slot}

De waardering van brede historisch-antropologische theorieën als Romeins A.M.P.-conceptie is juist vanwege hun alomvattende complexiteit, een moeilijke zaak. De A.M.P.-theorie wordt, zowel door antropologen als door historici, op harde kritiek onthaald. In Het A.M.P. en de volkenkundige (1957) verwijt de antropoloog A.J.F. Köbben Romein hoofdzakelijk alle niet-westerse maatschappijvormen over één kam te scheren. Voor historici is de theorie een 'grootscheepse, maar wankele conceptie' en met name Geyl oordeelt dat Romein het slachtoffer van de eigen systeemdwang is geworden. Te generaliserend en te theoretisch, zo wordt gedacht. Voor Romein biedt de A.M.P.-conceptię echter een ordeningsprincipe, dat afzonderlijke feitencomplexen kan verbinden. De negentiende eeuw is voor hem de eeuw van de deconstructie van de synthese geweest. In het nauwkeurig ophopen van vaststaande feiten als een losse hoop zandkorrels heeft Romein een desoriënterende werking onderkend. Een verdedigingsmechanisme tegen die desoriëntatie en de daarmee samenhangende onzekerheid zoekt hij in het opstellen van overkoepelende theorieën. In deze optiek 
blijft de taak van de cultuurgeschiedenis niet beperkt tot het memoreren van de historische ontwikkeling van de hogere geestesuitingen, zelfs niet tot een integrale geschiedschrijving. De cultuurgeschiedenis moet zoeken naar het overeenkomstige in de verschillende sferen van het maatschappelijk bestaan. $\mathrm{Zij}$ moet de cultuurmatrijs - met een hedendaagse term : het paradigma - van een bepaald tijdvak opstellen en de historische veranderingen van die matrijs registreren. Dat is precies wat de A.M.P.-theorie tracht te doen. Is de uitkomst té verleidelijk (er past zo veel in !), té speculatief ? Romein zelf heeft de theorie steeds als een 'anticiperend ontwerp' beschouwd. $\mathrm{Zij}$ is voor hem een Weberiaans ideaaltype, een rooster dat op de historische realiteit kan worden gelegd en op die manier een heuristische functie kan vervullen. De genealogie van het Afwijkingspatroon, het zoeken naar de erflaters van onze beschaving, toont dat dit tot belangrijke inzichten kan leiden.

Geyls onbegrip voor de A.M.P.-theorie houdt niet alleen verband met het vermeende formalistische karakter van die theorie. In zijn afscheidsrede in 1958, De vitaliteit van de westerse beschaving, onderneemt hij een kruistocht tegen 'het naieve illusionisme' van de universele geschiedschrijving, die de vaderlandse geschiedenis en de geschiedenis van de westerse cultuurgemeenschap als historiografisch uitgangspunt wou vervangen door een grotere wereldgerichtheid. Romeins A.M.P.-theorie ziet hij als een specimen bij uitstek van die nieuwe mode, die in Geyls ogen op onbezonnen wijze aan de vitaliteit en de waarde van de westerse beschaving voorbijgaat. Geyls standpunt blijkt echter te steunen op een .voorbijgestreefd eurocentrisme. "Romeins belangrijkste functie lag in het openbreken van verouderde kaders", zo luidt het eindoordeel van Brands over zijn leermeester. Eén van die verouderde historiografische kaders is precies Europa. De A.M.P.-theorie is een eerste aanzet tot een verruiming van het historisch perspectief. $\mathrm{Na}$ de Indonesië-reis krijgt deze nieuwe oriëntatie bij Romein ook vaste en concretere vormen in zijn onderwijs. In 1953 promoveert J. Pluvier bij hem op een proefschrift over de Indonesische nationalistische beweging in de jaren dertig en met Wertheim staat Romein aan de wieg van het Instituut voor Moderne Aziatische Geschiedenis aan de Universiteit van Amsterdam. Ondanks het feit dat hij tot op zekere hoogte schatplichtig blijft aan het oude evolutionisme (Blaas wijst in dit verband op de voorstelling van het A.M.P. als een stationaire beschaving), verzet hij de lichtbakens in de richting van een pluralistisch en tolerant cultuurrelativisme, dat met een open oog de niet-europese beschavingen leert waarderen en dat tegelijk als een nieuwe component aan het eigen westerse beschavingspatroon wordt toegevoegd en het verrijkt. 


\section{Literatuur}

Het basismateriaal voor deze tekst kan worden gevonden in J. Romein, Aera van Europa. De Europese geschiedenis als Afwijking van het Algemeen Menselijk Patroon (Leiden, 1954, in samenw. met A. Romein-Verschoor) en in id., De eeuw van Azië. Opkomst, ontwikkeling en overwinning van het modern-Aziatisch nationalisme (Leiden, 1956, in samenw. met J.E. Romein). In kortere studies werkt Romein telkens een deelaspect van deze problematiek uit. De belangrijkste zijn: De Europese geschiedenis als Afwijking van het Algemeen Menselijk Patroon, Het arbeidsbegrip in Oost en West, Herfsttij van Europa en De garoeda broedt. Indonesische indrukken 1952, opgenomen in de bundel In de ban van Prambanan. Indonesische voordrachten en indrukken (Amsterdam, 1954, resp. p. 21-57, p. 59-93, p. 95-126 en p. 169-213) en Het algemeen menselijk patroon. Ontstaan, belang en draagkracht van historische theorieën, Poging tot een herinterpretatie van het humanisme en Het conservatisme als historische categorie in de bundel Eender en anders. Twaalf nagelaten essays (Amsterdam, 1964, resp. p. 63-83, p. $85-98$ en p. 99-124). Een aantal van deze opstellen zijn herdrukt in $\mathrm{J}$. Romein, Historische lijnen en patronen. Een keuze uit de essays (Amsterdam, 1971). Onontbeerlijk voor een Romein-studie is A. Romein-Verschoor, Omzien in verwondering. Herinneringen ( $2 \mathrm{dln}$., Amsterdam, 1970-1971, in de reeks Privé-domein, nr. 17). Inleidende beschouwingen over Romein kunnen worden gevonden in A.F. Mellink, Jan Romein, - Historici van de twintigste eeuw, Antwerpen-Amsterdam, 1981, p. 199-215 en B.W. Schaper; Jan Marius Romein, - Jaarboek van de Maatschappij der Nederlandse Letterkunde te Leiden, 1963-1964, p. 77-89. Een selectie uit de nog steeds aangroeiende Romein-literatuur: M.C. Brands, Jan Romein en het ordeningsprincipe : tussen dwang en vrijheid. De dialectiek van emancipatie, - Theoretische Geschiedenis, 1985, jg. 12, nr. 4, p. 485-504; E.E.G. Vermeulen, Jan Romein tussen herdenking en hoop, - De Gids, 1981, dl. 144, p. 269-285 en W.F. Wertheim, De veranderlijke tijdsfactor, - P.B.M. Blaas (uitg.), Geschiedenis als wetenschap. Een bundel oude en nieuwe essays, Den Haag, 1979, p. 226-248. Tenslotte zij nog verwezen naar de twee herdenkingsnummers van De Nieuwe Stem, 1962, d1. 17, afl. 11-12 en naar het Annie Romein Verschoor-nummer van $B Z Z L L E T I N, 1980$, dl. 9, afl. 81, dat ook voor J. Romein belangrijk is. Een bibliografie van Romeins werk werd opgesteld door A. Tijhuis, P.A.L. Oppenheimer en M.C. Brands (Groningen, 1963). 